\title{
Simultaneous application of the vascular endothelial growth factor (VEGF) receptor inhibitor PTK787/ZK 222584 and ionizing radiation does not further reduce the growth of canine oral melanoma xenografts in nude mice
}

\author{
Inaugural-Dissertation \\ zur Erlangung der Doktorwürde der \\ Vetsuisse-Fakultät Universität Zürich \\ vorgelegt von \\ Natalie Inteeworn \\ Tierärztin von Neunkirchen/Saar, Deutschland \\ genehmigt auf Antrag von \\ Prof. Dr. med. vet. Barbara Kaser-Hotz, Referentin \\ Prof. Dr. med. vet. Max Gassman, Korreferent
}


Für meine Eltern 


\section{Table of contents}

$$
\text { page }
$$

$\begin{array}{ll}\text { Manuscript title } & 1\end{array}$

$\begin{array}{ll}\text { Abstract } & 2\end{array}$

Introduction 3

Material and Methods 5

$\begin{array}{ll}\text { Results } & 9\end{array}$

$\begin{array}{ll}\text { Discussion } & 10\end{array}$

$\begin{array}{ll}\text { Conclusion } & 13\end{array}$

$\begin{array}{ll}\text { Acknowledgements } & 14\end{array}$

$\begin{array}{ll}\text { References } & 15\end{array}$

$\begin{array}{ll}\text { Table } 1 & 18\end{array}$

$\begin{array}{ll}\text { Figure legends } & 20\end{array}$

$\begin{array}{ll}\text { Figure } 1 & 21\end{array}$

$\begin{array}{ll}\text { Figure } 2 & 22\end{array}$

$\begin{array}{ll}\text { Figure } 3 & 23\end{array}$

$\begin{array}{ll}\text { Danksagung } & 24\end{array}$ 
SIMULTANEOUS APPLICATION OF THE VASCULAR ENDOTHELIAL

GROWTH FACTOR (VEGF) RECEPTOR INHIBITOR PTK787/ZK 222584 AND

IONIZING RADIATION DOES NOT FURTHER REDUCE THE GROWTH OF

CANINE ORAL MELANOMA XENOGRAFTS IN NUDE MICE

Natalie Inteeworn ${ }^{\text {a }}$, Stefanie Ohlerth ${ }^{\text {a }}$, Gisele Höpfl ${ }^{\text {b }}$, Franco Guscetti ${ }^{\text {c }}$, Carla Rohrer Bley ${ }^{\text {a }}$, Melanie C Wergin ${ }^{\mathrm{a}}$, Malgorzata Roos ${ }^{\mathrm{d}}$, Max Gassmann ${ }^{\mathrm{b}}$, Barbara Kaser-Hotz ${ }^{\mathrm{a}}$ *

${ }^{\mathrm{a}}$ Section of Diagnostic Imaging and Radio-Oncology, ${ }^{\mathrm{b}}$ Institute of Veterinary Physiology, ${ }^{\mathrm{c}}$ Institute of Veterinary Pathology, Vetsuisse Faculty, ${ }^{\mathrm{d}}$ Institute of Social and Preventive Medicine, Department of Biostatistics, University of Zürich, Switzerland

Grant support: Margret und Francis Fleitmann Stiftung; Forschungskredit 2002, University of Zürich; Swiss National Foundation, Grant number: 3100AO-100214

*Corresponding author: Tel.: + 41-1 635 8449; fax: + 41-1 6358940

E-mail address: bkaser@vetclinics.unizh.ch (B. Kaser-Hotz)

\# this work was conducted in the context of a doctoral thesis (N.I.) 


\section{ABSTRACT}

We tested the effectiveness of PTK787/ZK 222584, an inhibitor of the vascular endothelial growth factor (VEGF) receptor tyrosine kinases, when applied together with radiation on canine oral melanoma xenografts. Xenografts were treated with radiotherapy (4 x 6 Gy), PTK787/ZK 222584, or with a combination of both. Treatment efficacy was assessed using a tumour growth delay assay, serial power Doppler and $\mathrm{pO}_{2}$ measurements during and after therapy. There was a significant growth delay for the group treated with radiation alone and for the combined treatment group; however, tumour growth delay was similar in both groups. Tumours were hypoxic before irradiation and no significant re-oxygenation occurred during therapy. In all tumours, vascularity and perfusion were significantly lower at the end of the study but no significant differences in perfusion, vascularity and oxygenation status were observed between and within treatment groups. The combination of PTK787/ZK 222584 and radiotherapy was not advantageous over radiotherapy alone in this model.

Keywords: canine melanoma xenograft, PTK787/ZK 222584, radiotherapy, power Doppler ultrasonography, $\mathrm{pO}_{2}$ 


\section{INTRODUCTION}

Angiogenesis, the process of new blood vessel formation, is a rare phenomenon in healthy adults, occurring only locally and transiently under distinctive physiological conditions such as wound healing, inflammation, and the female reproductive cycle. In contrast, the switch to an angiogenic phenotype is known to be critical for tumour progression. Unless a tumour can stimulate the formation of new blood vessels, it remains restricted to a microscopic size (Folkman, 1995).

A variety of very potent angiogenic activators are commonly expressed in many tumour types and enhance the proliferation of both endothelial and tumour cells (Graeven et al., 2001; Rofstad and Halsor, 2000). Among them, vascular endothelial growth factor (VEGF) is considered as one of the major and best studied molecules responsible for tumour angiogenesis (McMahon, 2000). Therefore, it is reasonable to inhibit tumour angiogenesis and especially the VEGF/VEGFR signalling pathway as a new method of tumour treatment. This treatment is mainly targeting immature blood vessels, which are dependent on constant VEGF signalling for survival (Benjamin et al., 1999). Many studies recommend a combination of angiogenesis inhibitors with conventional therapies, e.g. with chemotherapy (Baker et al., 2002; Teicher et al., 1992) or ionizing radiation (Wachsberger et al., 2003). A class of drugs that holds promising results is small inhibitory molecules that block the receptor tyrosine kinase signalling pathways. Among them, PTK787/ZK 222584 is an orally bioavailable, potent and selective inhibitor of all VEGFR-tyrosine kinases. In murine xenograft models, PTK787/ZK 222584 showed good efficacy in inhibiting the growth of human carcinomas when given alone (Drevs et al., 2000; Wood et al., 2000) or in combination with chemo- or radiation therapy (Baker et al., 2002; Hess et al., 2001). In a xenograft mouse model the vasculature is build by the host organism (Folkmann et al. 1995) 
allowing the tumour to grow. The pharmacological activity of PTK787/ZK 222584 on the vasculature of nude mice has been demonstrated (Lee, 2005, Wood et al., 2000).

Malignant melanoma is the most common oral tumour in dogs and is considered a very aggressive local and systemic disease with a poor prognosis. Conventional therapy is limited and usually consists of palliative treatment such as surgery and/or radiation therapy to gain local control (Withrow, 2001). We have previously shown that plasma VEGF is elevated in dogs with tumours including melanoma (Wergin and Kaser-Hotz, 2004) implying that the inhibition of the VEGF/VEGFR signalling pathway together with ionizing radiation might be a useful way of improving local control of the tumour and to increase survival time of patients affected with this aggressive disease.

We therefore designed a canine malignant melanoma xenograft model in mice to assess if PTK787/ZK 222584 given before each fraction of radiation therapy would have an additive effect. A clinically relevant and effective dose of ionizing radiation combined with a dose of PTK787/ZK 222584 previously shown to have a radio-sensitising effect in vitro and in vivo (Hess et al., 2001) was given. With this combined treatment approach we expected to see changes in tumour vascularity and oxygenation. Therefore, serial contrast-enhanced power Doppler ultrasonography was performed to monitor changes in tumour vascularity and perfusion. At the same time points, the intra-tumoural oxygen tension was determined since hypoxia is considered to be one of the major factors leading to radio-resistance of tumour cells. 


\section{MATERIALS AND METHODS}

\section{Establishing a Melanoma Cell Line.}

We established the M2 cell line from a primary malignant oral amelanotic melanoma of an 11-year-old male Golden Retriever dog. Immediately after surgery, a tumour biopsy was dissected and digested with $0.1 \%$ collagenase, $0.05 \%$ protease Type I and $0.002 \%$ DNAse (all obtained from Sigma) and diluted in Dulbecco’s modified Eagle’s medium (DMEM) (Life technologies, Inc.). The resulting single cell suspension was washed with PBS and incubated in DMEM supplemented with GlutaMax, sodium pyruvate, non-essential amino acids, antibiotics (Penicillin/Streptomycin, $1 \mathrm{x}$ final conc.) (all purchased from Life Technologies, Inc.) and 20\% heat-inactivated foetal calf serum (FCS) (Boehringer Mannheim GmbH). Cells were cultured at $37^{\circ} \mathrm{C}$ in a humidified atmosphere with $5 \% \mathrm{CO}_{2}$. After 5 passages, the concentration of FCS was gradually reduced to $10 \%$. Immunohistochemistry of the original tumour tissue revealed reactivity with antibodies against the melanoma-specific antigens MelanA and PNL2. Immunohistochemistry of cultured cells with antibodies against MelanA and PNL2 yielded a positive result in over $20 \%$ of the cells at passage 3 . Tumourigenicity was confirmed by subcutaneous injection of $1 \times 10^{7} \mathrm{M} 2$ cells in the left flank region of four sixweek-old female Swiss nu/nu mice (Charles River Laboratories). Histopathological analysis of xenograft tumour tissue revealed a melanocytic cell type similar to the original tumour. In addition, a band of the expected size was amplified in a PCR with canine-specific primers for p53 exon 5 from extracts of xenograft tissue but not from tissue samples originated from a mouse lymph node, indicating that the tumour tissue was indeed of canine origin.

\section{In vivo tumour model.}

Four-week-old, female Swiss nu/nu mice, caged in groups of five to six animals, were treated according to institutional guidelines approved by the Kantonales Veterinäramt Zürich. 
For the establishment of xenografts, $100 \mu$ l of a single cell suspension of subconfluent M2 canine melanoma cells was inoculated subcutaneously within the left upper thigh region (total number of animals $=36$ ). Tumour size was measured with a calliper twice a week, and tumour volume was estimated according to the formula: volume $=1 / 2 \mathrm{x}$ length $\mathrm{x}$ width ${ }^{2}$. Mice were sacrificed by cervical dislocation when tumours reached a volume of $1500 \pm 150 \mathrm{~mm}^{3}$. Tumour tissue was immediately resected and snap-frozen in isopentane (Fluka)/liquid nitrogen and stored at $-80^{\circ} \mathrm{C}$.

\section{Treatment.}

When tumours reached a volume of $500 \pm 50 \mathrm{~mm}^{3}$, animals were randomly assigned into four groups ( $\mathrm{n}=8-11)$ and treated as following: group 1: oral application of PTK787/ZK 222584 (Novartis AG, Schering AG); group 2: radiation; group 3: radiation in combination with PTK787/ZK 222584; group 4: untreated control. PTK787/ZK 222584 was given on four consecutive days at a dosage of $100 \mathrm{mg} / \mathrm{kg}$ body weight. The drug ( $5 \mathrm{mg} / \mathrm{mL}$ ) was suspended in 5\% DMSO, 1\% Tween 80 and given orally. Radiation treatment was applied using $6 \mathrm{MeV}$ electrons from a linear accelerator (Dynaray LA20, ABB, Varian). In order to achieve a homogenous dose build up and distribution, a one cm bolus was placed over the irradiated field. Treatment was given in four 6 Gy fractions on consecutive days. Mice were anaesthetised with intra-peritoneal injections of ketamine (100 mg/kg, Vétoquinol) and xylazine (20 mg/kg, Streuli) and positioned on a heating pad during the procedure. In the combined treatment group, PTK787/ZK 222584 was administered 30 minutes prior to radiation. 


\section{Tumour Growth Delay Assay.}

Treatment efficacy was assessed using a tumour growth delay assay. Tumour growth delay was defined as the mean time for tumours in the treated groups to reach $1500 \mathrm{~mm}^{3}$ minus the time for the control group to reach the same size.

\section{Power Doppler Ultrasonography and $\mathrm{pO}_{2}$ Measurements.}

Contrast-enhanced power Doppler ultrasonography (US) and subsequent $\mathrm{pO}_{2}$ measurements were performed immediately prior to the first and fourth treatment, on days four and eight post-treatment and when tumours had reached their final size. All mice were anaesthetised and handled as described above. Imaging was performed using a 5 - $12 \mathrm{MHz}$ linear transducer (ATL 5000, Philips AG). Power Doppler settings were held constant across all examinations (colour gain 81\%, medium wall filter, $500 \mathrm{~Hz}$ pulse repetition frequency, low velocity flow estimation, maximal depth $25 \mathrm{~mm}$, frame rate 10 - $12 \mathrm{~Hz}$ ). The ultrasound contrast agent was a first-generation microbubble suspension (Levovist, Schering AG (400 $\mathrm{mg} / \mathrm{mL})$ ). Initial scanning of the entire tumour was performed with B-mode to define its boundary and morphology. A rectangular sample volume was then placed over the tumour and immediate surrounding tissue, denoting the region in which power Doppler data would be acquired. After the slow intravenous injection of $0.1 \mathrm{~mL}$ contrast medium, a minimum of five power Doppler images was obtained throughout the tumour after blooming artefacts had disappeared. Computerized image analysis was performed using a dedicated software (Qwin, Leica Microsystems AG) and similar to the method by Fleischer et al. (1999), three parameters were computed for each region of interest: fractional area (FA), mean colour level (MCL), and colour-weighted fractional area (CWFA). FA represents a vascularity index and both MCL and CWFA assess perfusion. Computerized parameters were determined for postcontrast power Doppler by calculating the median of each set of five images. 
Using a sterile needle electrode (Helzel Medical System) tumour oxygen tensions were measured polarographically after the ultrasound procedure as described elsewhere (Achermann et al., 2002; Höckel et al., 1991; Kallinowski et al., 1990; Vaupel et al., 1991). The needle electrode was placed within the tumour tissue and after an adaptation time, at least 30 values were collected in $1-2$ different tracks. The measurement inaccuracy of the device was $+/-1.5 \mathrm{~mm} \mathrm{Hg}$ and negative values of $\geq-1.5 \mathrm{mmHg}$ were defined as $\mathrm{pO}_{2}=0 \mathrm{mmHg}$. Data, which consisted of less than 10 reliable readings, were not used for statistical analyses.

\section{Statistical Analysis.}

Experimental data is presented as means \pm standard deviation unless otherwise stated and 95\% confidence intervals of the means (95\% CI). Statistical comparison of means between treatment groups was performed using Kruskal-Wallis test or one-way ANOVA with post-hoc tests (Bonferroni Dunn method) for normally distributed data. If necessary, variables were transformed using the natural logarithm. For the tumour growth delay analysis, the difference of the means together with the corresponding 95\% CI were calculated according to Sachs (Sachs, 1997). For serial ultrasound and $\mathrm{pO}_{2}$ measurements, differences of values at a certain time point during or after treatment to the baseline values (prior to treatment) were calculated to eliminate variability of the baseline values. In order to assess multiple measurements over time in the same animal, repeated measures analysis with the GreenhouseGeisser correction was used in order to analyse the differences in vascularity, perfusion and $\mathrm{pO}_{2}$ between treatment groups and to determine their association with time. A $P$-Value $<5 \%$ was considered significant. Statistical analysis was performed with StatView (SAS Institute Inc., Version 6.0.1) and SPSS (SPSS Schweiz AG, Version 10.8). 


\section{RESULTS}

\section{Effect of PTK787/ ZK222584 and Ionizing Radiation on Growth of Canine Melanoma Xenografts.}

Treatment was initiated when M2 xenografts reached a volume of $500 \pm 50 \mathrm{~mm}^{3}$ (after a mean of $90.8 \pm 15.9$ days). PTK787/ZK 222584 alone did not significantly delay tumour progression compared to the untreated control group. In contrast, radiation therapy as well as the combined treatment of radiation and PTK787/ZK 222584 caused a highly significant growth delay compared to the control group (Fig. 1A). The mean tumour growth delay of treated tumours to triplicate their volume was 30.2 days (95\% CI: 18.3, 42.0) in the radiation group and 30.9 days, (95\% CI: 18.4, 43.4) in the combined treatment group $(\mathrm{P}<0.0001)$. Tumour growth delay was similar in the group treated with radiation alone and for the combined treatment group. The mean tumour growth delay in the PTK787/ZK 222584-treated group was only 0.63 days compared to the control, (95\% CI: -8.2, 9.5) (Fig. 1B).

\section{Treatment Effect on Tumour Vascularity and Perfusion.}

Prior to treatment, low median values were found for vascularity (FA: 7.24\%) and perfusion (CWFA: 3.22, MCL: 38.41). Concerning perfusion (CWFA) of tumours, neither an influence of time $(P=0.773)$ nor differences between groups $(P=0.931)$ were found during and after treatment (Fig. $2 A)$. Similar results $(P=0.787$ and $P=0.893$, respectively) were found for the vascularity parameter FA (Fig. 2B). However, at the end of the experiment, all tumours were significantly less vascularised and perfused than prior to treatment $(P=0.0013$ for CWFA and $P=0.0002$ for FA) (Fig. 2, 3). 


\section{Tumour Oxygenation During and After Therapy.}

The mean $\mathrm{pO}_{2}$ of all tumours at the beginning of the study was $2.4 \mathrm{mmHg}$, (95\% CI: 1.3, 3.5). $\mathrm{PO}_{2}$ readings below $2.5 \mathrm{~mm} \mathrm{Hg}$ were measured in $63 \%$ of the tumours, values below $5 \mathrm{~mm} \mathrm{Hg}$ in 73\%. Although not statistically significant, a mild increase in tumour oxygenation was observed in all treatment groups during therapy, whereas thereafter, $\mathrm{pO}_{2}$ gradually decreased in all tumours. No significant changes of the $\mathrm{pO}_{2}$ were found between and within groups (Table 1).

\section{DISCUSSION}

Malignant melanoma in the oral cavity of dogs is an aggressive local and systemic disease with a poor prognosis. Established treatment methods such as surgery and/or radiation therapy are palliative and limited to local control (Rassnick et al., 2001). Hence, the development of new treatment strategies to improve survival is needed urgently. The importance of VEGF for progression and metastasis of human melanoma has been demonstrated (Graeven et al., 2001; Rofstad and Halsor, 2000). Since VEGF protein has been shown to be augmented in the plasma of tumour bearing dogs including melanoma (Wergin and Kaser-Hotz, 2004), we aimed at exploring the effectiveness of PTK787/ZK 222584, a specific, low molecular inhibitor of the VEGF receptor tyrosine kinases, when administered in combination with a routinely applied hypofractionated radiation scheme of four fractions of 6 Gy.

Our study revealed that pre-treatment with PTK787/ZK 222584 does not enhance the growth-retarding effect of ionizing radiation on our canine melanoma xenograft model. The tumour growth delay was similar in the combined treatment group and the radiation only 
group, suggesting that the observed delay was only due to radiation therapy (Fig.1A). Previous in vitro studies suggested that four doses of PTK787/ZK 222584 combined with irradiation exert a potential radiosensitization and anti-proliferative effect on intra-tumoural endothelial cells resulting in a supra-additive, anti-tumoural effect on colon adenocarcinoma xenografts in nude mice (Hess et al., 2001). However, recent work showed no additional growth delay effect of PTK787/ZK 222584 when administered concomitantly before each fraction of radiation therapy (Zips et al., 2003). In contrast, when PTK787/ZK 222584 was applied in an adjuvant setting after the completion of a fractionated course of irradiation, it significantly inhibited tumour growth. Therefore, the optimal timing and sequencing of PTK787/ZK 222584 in the combined treatment of canine melanoma xenografts needs further investigation.

We chose the treatment starting size of $500 \mathrm{~mm}^{3}$ to mimic the clinical situation with dogs having large, substantial tumours to be treated with radiation therapy. Our results indicate that treatment of already established malignant melanoma with PTK787/ZK 222584 as a radiosensitizer is likely of limited success. This is in accordance with other studies suggesting that blocking growth signalling pathways in large tumours might be less effective than in small tumours (Sweeney et al., 2002; Yoshiji et al., 1997). The maturity of blood vessels appears to be another critical factor for the success of antiangiogenic therapy. Immature vessels, which lack pericyte coverage, are dependent on VEGF for survival, whereas solid tumours with mature vessels are less responsive (Benjamin et al., 1999).

Since angiogenesis inhibitors act directly on endothelial cells and not tumour cells, clinical monitoring of tumour regression during therapy only partially reflects treatment efficacy. In the present study, power Doppler US was used to non-invasively assess tumour vascularity and perfusion during antiangiogenic therapy. Contrast-enhanced power Doppler 
US has been shown to be the most sensitive Doppler technology for detecting low velocities and small parenchymal vessels e.g. in tumours (Schroeder et al., 2001). An additional advantage of power Doppler is the ability to survey the entire tumour vasculature reflecting anatomic and physiologic characteristics without perturbing the tumour being studied. Power Doppler US has also been described to monitor the effect of irradiation on tumour vasculature (Denis et al., 2003). In the present study, computerised image analysis was performed to determine the parameters FA (vascularity) and MCL and CWFA (perfusion). However, significant differences in vascularity and perfusion were found neither within nor between groups during and after treatment. Overall, baseline Doppler vascularity and perfusion in the tumours was low (Fig.2), which may have hampered the occurrence of significant differences during the course of treatment. In naturally occurring canine oral melanomas, our group found moderate vascularity and perfusion in contrast to highly vascularised and perfused squamous cell carcinomas and sarcomas with low vascularity and perfusion (Ohlerth et al., 2004). Therefore, the xenograft model used in the present study may not have adequately represented the biological vascularity and perfusion of canine oral melanomas. Interestingly, at the end of the experiment, all tumours were significantly less vascularised and perfused than prior to or during the course of treatment, but significant differences between treatment groups were not found. Depending on the tumour stage, perfusion and vascular pattern of a tumour may have a variable presentation. When tumours are small, high-flow states are a prominent feature because of arteriovenous shunts. As tumours enlarge, the high-flow areas become peripheral and poor perfusion in the central areas is common (Denis et al., 2003).

Radiation has been shown to influence intra-tumoural $\mathrm{pO}_{2}$ values in experimental and clinical studies (Brizel et al., 1999; Nordsmark et al., 1996). Only few experimental studies in different rodent xenografts describe the oxygenation status during fractionated irradiation and illustrate the heterogeneity of serial changes in tumour oxygenation (Baumann et al., 2001; Stüben et al., 1999; Zywietz et al., 1995). There are only a few preclinical studies that 
examined the effect of angiogenesis inhibitors combined with radiation therapy. The type of antiangiogenic drug that is being used and the tumour type might be of great importance for the effect on $\mathrm{pO}_{2}$ during a course of fractionated radiation, as shown in previous studies. (Lee et al., 2000; Teicher et al., 1995). To our knowledge, no study has addressed the kinetics of the oxygenation status when a combined therapy approach was used. We were therefore interested to evaluate how these therapies would influence the intra-tumoural oxygen tensions in canine melanoma xenografts. Pre-treatment, all tumours were severely hypoxic with a mean total $\mathrm{pO}_{2}$ of $2.4 \mathrm{~mm} \mathrm{Hg}$ and a frequency distribution of values below $2.5 \mathrm{~mm} \mathrm{Hg}$ of $64 \%$ and values below $5 \mathrm{~mm} \mathrm{Hg}$ of $86 \%$. During and after completion of therapy, the oxygenation status remained unchanged (Table 1). As for the radiation therapy treated group, we confirmed previous results on human squamous cell carcinoma and rhabdomyosarcoma xenografts, where the $\mathrm{pO}_{2}$ did not change significantly during a course of fractionated radiation (Baumann et al., 2001; Zywietz et al., 1995). Although there was no improvement of the oxygenation status during therapy, one could argue that the oxygenation status does not impair with fractionated radiation therapy as seen by Teicher et. al. (1994) on studies on rat mammary carcinoma. Interestingly, the use of PTK787/ZK 222584 either alone or in combination had no influence on the $\mathrm{pO}_{2}$ and the frequency distribution of values below 2.5 and $5 \mathrm{~mm} \mathrm{Hg}$. These results are in analogy with already mentioned studies using TNP-470 or neutralizing VEGF antibodies (Lee et al., 2000; Teicher et al., 1995).

\section{CONCLUSION}

In conclusion, the chosen radiation protocol effectively produced a growth delay in a canine oral melanoma xenograft model. When PTK787/ZK 222584 was used as a possible radiosenitiser in combination with fractionated radiation therapy, no additive effect on the 
growth delay was seen. Further studies are clearly needed using smaller tumour treatment sizes along with a change of the drug schedule in relation to radiation therapy. In addition, the drug has to be assessed in more than one canine melanoma cell line to better outline its effect on canine patients suffering from oral malignant melanoma. Power Doppler and intratumoural oxygen tension measurement are believed to be valuable tools in assessing treatment effect.

\section{ACKNOWLEDGMENTS}

We thank Dr. Jeanette Wood for supplying PTK787/ZK 222584 and Dres. Martin Pruschy, Johannes Vogel, Lara Ogunshola and Thomas Hofer for helpful discussions or critical editorial review. Finally, we appreciate the excellent technical assistance of Bianca Saam, Stephan Keller and Beat Grenacher. 


\section{REFERENCES}

Achermann, R., Ohlerth, S., Fidel, J., Gardelle, O., Gassmann, M., Roos, M., Saunders, H.M., Scheid, A., Wergin, M., Kaser-Hotz, B., 2002. Ultrasound guided, pre-radiation oxygen measurements using polarographic oxygen needle electrodes in spontaneous canine soft tissue sarcomas. In Vivo 16, 431-437.

Baker, C.H., Solorzano, C.C., Fidler, I.J., 2002. Blockade of vascular endothelial growth factor receptor and epidermal growth factor receptor signalling for therapy of metastatic human pancreatic cancer. Cancer Research 62, 1996-2003.

Baumann, M., Appold, S., Zimmer, J., Scharf, M., Beuthien-Baumann, B., Dubben, H.H., Enghardt, W., Schreiber, A., Eicheler, W., Petersen, C., 2001. Radiobiological hypoxia, oxygen tension, interstitial fluid pressure and relative viable tumour area in two human squamous cell carcinomas in nude mice during fractionated radiotherapy. Acta Oncologica 40, 519-528.

Benjamin, L.E., Golijanin, D., Itin, A., Pode, D., Keshet, E., 1999. Selective ablation of immature blood vessels in established human tumors follows vascular endothelial growth factor withdrawal. Journal of Clinical Investigation 103, 159-165.

Brizel, D.M., Dodge, R.K., Clough, R.W., Dewhirst, M.W., 1999. Oxygenation of head and neck cancer: changes during radiotherapy and impact on treatment outcome. Radiotherapy and Oncology 53, 113-117.

Denis, F., Bougnoux, P., Paon, L., le Floch, O., Tranquart, F., 2003. Radiosensitivity of rat mammary tumors correlates with early vessel changes assessed by power Doppler sonography. Journal of Ultrasound in Medicine 22, 921-929.

Drevs, J., Hofmann, I., Hugenschmidt, H., Wittig, C., Madjar, H., Müller, M., Wood, J., Martiny-Baron, G., Unger, C., Marmé, D., 2000. Effects of PTK787/ZK 222584, a specific inhibitor of vascular endothelial growth factor receptor tyrosine kinases, on primary tumor, metastasis, vessel density, and blood flow in a murine renal cell carcinoma model. Cancer Research 60, 4819-4824.

Fleischer, A.C., Wojcicki, W.E., Donnelly, E.F., Pickens, D.R., Thirsk, G., Thurman, G.B., Hellerqvist, C.G., 1999. Quantified color Doppler sonography of tumor vascularity in an animal model. Journal of Ultrasound in Medicine 18, 547-551.

Folkman, J., 1995. Angiogenesis in cancer, vascular, rheumatoid and other disease. Nature Medicine 1, 27-31.

Graeven, U., Rodeck, U., Karpinski, S., Jost, M., Philippou, S., Schmiegel, W., 2001. Modulation of angiogenesis and tumorigenicity of human melanocytic cells by vascular endothelial growth factor and basic fibroblast growth factor. Cancer Research 61, 7282-7290.

Hess, C., Vuong, V., Hegyi, I., Riesterer, O., Wood, J., Fabbro, D., Glanzmann, C., Bodis, S., Pruschy, M., 2001. Effect of VEGF receptor inhibitor PTK787/ZK222584 [correction of ZK222548] combined with ionizing radiation on endothelial cells and tumour growth. British Journal of Cancer 85, 2010-2016.

Höckel, M., Schlenger, K., Knoop, C., Vaupel, P., 1991. Oxygenation of carcinomas of the uterine cervix: evaluation by computerized $\mathrm{O}_{2}$ tension measurements. Cancer Research 51, 6098-6102.

Kallinowski, F., Zander, R., Höckel, M., Vaupel, P., 1990. Tumor tissue oxygenation as evaluated by computerized-pO $\mathrm{P}_{2}$-histography. International Journal of Radiation Oncology Biology Physics 19, 953-961.

Ohlerth, S., Laluhovà, D., Wergin, M., Rohrer-Bley, C., Melzer, K., Roos, M., Kaser-Hotz, B., 2004. Assessment of vascularity and perfusion in spontaneous canine tumors with contrast-enhanced Doppler ultrasound before and during fractionated radiation therapy. In: Abstracts of oral and peer poster presentations American College of 
Veterinary Radiology Annual Meeting, Montreal, Canada. Vet Radiology and Ultrasound 45, p. 492.

Lee, C.G., Heijn, M., di Tomaso, E., Griffon-Etienne, G., Ancukiewicz, M., Koike, C., Park, K.R., Ferrara, N., Jain, R.K., Suit, H.D., Boucher, Y., 2000. Anti-vascular endothelial growth factor treatment augments tumor radiation response under normoxic or hypoxic conditions. Cancer Research 60, 5565-5570.

Lee, L., Sarma, S., Morgan, B., Allegrini, P., Schnell, C., Brueggen, J., Cozens, R., Horsfield, M., Guenher, C., Steward, W.P., Drevs, J., Lebwohl, D., Wood, J., Mc Sheehy, P.M., 2005. Biomarkers for assessment of pharmacological activity for a vascular endothelial growth factor (VEGF) receptor inhibitor, PTK 787/ZK 222584(PTK/ZK): translation of biological activity in a mouse melanoma metastasis model to phase I studies in patients with advanced colorectal cancer with liver metastases. Cancer Chemotherapy and Pharmacology 20,1-11.

McMahon, G., 2000. VEGF receptor signalling in tumor angiogenesis. Oncologist 5, 3-10. Nordsmark, M., Overgaard, M., Overgaard, J., 1996. Pre-treatment oxygenation predicts radiation response in advanced squamous cell carcinoma of the head and neck. Radiotherapy and Oncology 41, 31-39.

Rassnick, K.M., Ruslander, D.M., Cotter, S.M., Al-Sarraf, R., Bruyette, D.S., Gamblin, R.M., Meleo, K.A., Moore, A.S., 2001. Use of carboplatin for treatment of dogs with malignant melanoma: 27 cases (1989-2000). Journal of the American Veterinary Medical Association 218, 1444-1448.

Rofstad, E.K., Halsor, E.F., 2000. Vascular endothelial growth factor, interleukin 8, plateletderived endothelial cell growth factor, and basic fibroblast growth factor promote angiogenesis and metastasis in human melanoma xenografts. Cancer Research 60, 4932-4938.

Sachs, L., 1997. In: Angewandte Statistik, Anwendung statistischer Methoden. SpringerVerlag, Berlin, Heidelberg, p 355.

Schroeder, R.J., Hauff, P., Bartels, T., Vogel, K., Jeschke, J., Hidajat, N., Maeurer, J., 2001. Tumor vascularization in experimental melanomas: correlation between unenhanced and contrast enhanced power Doppler imaging and histological grading. Ultrasound in Medicine and Biology 27, 761-771.

Stüben, G., Thews, O., Pöttgen, C., Stuschke, M., Sack, H., 1999. Tumour oxygenation during fractionated radiotherapy - comparison with size-matched controls. Acta Oncologica 38, 209-213.

Sweeney, P., Karashima, T., Kim, S.J., Kedar, D., Mian, B., Huang, S., Baker, C., Fan, Z., Hicklin, D.J., Pettaway, C.A., Dinney, C.P., 2002. Anti-vascular endothelial growth factor receptor 2 antibody reduces tumorigenicity and metastasis in orthotopic prostate cancer xenografts via induction of endothelial cell apoptosis and reduction of endothelial cell matrix metalloproteinase type 9 production. Clinical Cancer Research 8, 2714-2724.

Teicher, B.A., Sotomayor, E.A., Huang, Z.D., 1992. Antiangiogenic agents potentiate cytotoxic cancer therapies against primary and metastatic disease. Cancer Research 52, 6702-6704.

Teicher, B.A., Dupuis, N.P., Robinson, M.F., Kusumoto, T., Liu, M., Menon, K., 1994. Reduced oxygenation in a rat mammary carcinoma post-radiation and reoxygenation with a perflubron emulsion/carbogen breathing. In Vivo 8, 125-131.

Teicher, B.A., Holden, S.A., Ara, G., Dupuis, N.P., Liu, F., Yuan, J., Ikebe, M., Kakeji, Y., 1995. Influence of an anti-angiogenic treatment on 9L gliosarcoma: oxygenation and response to cytotoxic therapy. International Journal of Cancer 61, 732-737. 
Vaupel, P., Schlenger, K., Knoop, C., Höckel, M., 1991. Oxygenation of human tumors: evaluation of tissue oxygen distribution in breast cancers by computerized $\mathrm{O}_{2}$ tension measurements. Cancer Research 51, 3316-3322.

Wachsberger, P., Burd, R., Dicker, A.P., 2003. Tumor response to ionizing radiation combined with antiangiogenesis or vascular targeting agents: exploring mechanisms of interaction. Clinical Cancer Research 9, 1957-1971.

Wergin, M.C., Kaser-Hotz, B., 2004. Plasma vascular endothelial growth factor (VEGF) measured in seventy dogs with spontaneously occurring tumours. In Vivo 18, 15-19.

Withrow, S.J., 2001. Cancer of the oral cavity. In: Withrow,S.J., MacEwen, E.G. (Eds.), Small Animal Clinical Oncology. W.B. Saunders Company, Philadelphia, pp 307-310.

Wood, J.M., Bold, G., Buchdunger, E., Cozens, R., Ferrari, S., Frei, J., Hofmann, F., Mestan, J., Mett, H., O'Reilly, T., Persohn, E., Rösel, J., Schnell, C., Stover, D., Theuer, A., Towbin, H., Wenger, F., Woods-Cook, K., Menrad, A., Siemeister, G., Schirner, M., Thierauch, K.H., Schneider, M.R., Drevs, J., Martiny-Baron, G., Totzke, F., Marmé, D., 2000. PTK787/ZK 222584, a novel and potent inhibitor of vascular endothelial growth factor receptor tyrosine kinases, impairs vascular endothelial growth factorinduced responses and tumor growth after oral administration. Cancer Research 60, 2178-2189.

Yoshiji, H., Harris, S.R., Thorgeirsson, U.P., 1997. Vascular endothelial growth factor is essential for initial but not continued in vivo growth of human breast carcinoma cells. Cancer Research 57, 3924-3928.

Zips, D., Krause, M., Hessel, F., Westphal, J., Brüchner, K., Eicheler, W., Dörfler, A., Grenman, R., Petersen, C., Haberey, M., Baumann, M., 2003. Experimental study on different combination schedules of VEGF-receptor inhibitor PTK787/ZK222584 and fractionated irradiation. Anticancer Research 23, 3869-3876.

Zywietz, F., Reeker, W., Kochs, E., 1995. Tumor oxygenation in a transplanted rat rhabdomyosarcoma during fractionated irradiation. International Journal of Radiation Oncology Biology Physics 32, 1391-1400. 
Table 1: Oxygenation of M2 melanoma xenografts during and after therapy

\begin{tabular}{|c|c|c|c|c|}
\hline Measurement ${ }^{\mathrm{a}}$ & Group & $\begin{array}{l}\text { mean } \mathrm{pO}_{2} \\
(\mathrm{mmHg})^{\mathrm{b}}\end{array}$ & $\begin{array}{l}\text { Values (\%) } \\
<2.5 \text { mmHg } \\
\text { b }\end{array}$ & $\begin{array}{l}\text { Values (\%) } \\
<5 \text { mmHg }^{\mathrm{b}}\end{array}$ \\
\hline \multirow[t]{4}{*}{ Day 1} & Control & $1.5 \pm 0.7$ & $76 \pm 11$ & $85 \pm 7$ \\
\hline & PTK787 c & $3.2 \pm 1.0$ & $53 \pm 12$ & $68 \pm 9$ \\
\hline & $\mathrm{RT}^{\mathrm{d}}$ & $1.0 \pm 0.5$ & $74 \pm 6$ & $81 \pm 5$ \\
\hline & $\mathrm{RT}+\mathrm{PTK} 787^{\mathrm{c}, \mathrm{d}}$ & $3.5 \pm 1.5$ & $55 \pm 13$ & $62 \pm 12$ \\
\hline \multirow[t]{4}{*}{ Day 4} & Control & $4.6 \pm 2.2$ & $44 \pm 20$ & $50 \pm 20$ \\
\hline & PTK787 & $3.7 \pm 1.3$ & $54 \pm 14$ & $61 \pm 11$ \\
\hline & RT & $3.3 \pm 1.9$ & $60 \pm 14$ & $68 \pm 12$ \\
\hline & RT + PTK787 & $4.9 \pm 1.6$ & $40 \pm 12$ & $51 \pm 13$ \\
\hline \multirow[t]{4}{*}{ Day 8} & Control & $4.2 \pm 1.5$ & $46 \pm 12$ & $68 \pm 12$ \\
\hline & PTK787 & $3.7 \pm 2.4$ & $61 \pm 19$ & $63 \pm 19$ \\
\hline & $\mathrm{RT}$ & $2.7 \pm 2.0$ & $74 \pm 14$ & $81 \pm 11$ \\
\hline & RT + PTK787 & $2.3 \pm 1.3$ & $71 \pm 10$ & $77 \pm 10$ \\
\hline \multirow[t]{4}{*}{ Day 12} & Control & $0.9 \pm 0.3$ & $82 \pm 6$ & $90 \pm 4$ \\
\hline & PTK787 & $1.8 \pm 1.1$ & $74 \pm 9$ & $84 \pm 7$ \\
\hline & $\mathrm{RT}$ & $1.2 \pm 0.6$ & $80 \pm 9$ & $90 \pm 6$ \\
\hline & RT + PTK787 & $0.1 \pm 0.0$ & $98 \pm 1$ & $99 \pm 1$ \\
\hline \multirow[t]{4}{*}{ End } & Control & $2.3 \pm 2.0$ & $85 \pm 9$ & $86 \pm 9$ \\
\hline & PTK787 & $0.9 \pm 0.9$ & $80 \pm 10$ & $87 \pm 7$ \\
\hline & $\mathrm{RT}$ & $1.9 \pm 1.7$ & $84 \pm 9$ & $86 \pm 9$ \\
\hline & $\mathrm{RT}+\mathrm{PTK} 787$ & $0.6 \pm 0.6$ & $86 \pm 10$ & $91 \pm 7$ \\
\hline
\end{tabular}

Table 1: Oxygenation of M2 melanoma xenografts during and after therapy 
${ }^{\mathrm{a}}$ Measurements were performed on days 1 and 4 of treatment, 4 and 8 days later and finally with an end size of $1500 \pm 150 \mathrm{~mm}^{3}$

${ }^{\mathrm{b}}$ mean $\pm \mathrm{SE}(\mathrm{n}=8-11$ animals/group)

${ }^{\mathrm{c}}$ PTK787/ZK 222584 was administered at a dose of $100 \mathrm{mg} / \mathrm{kg}$

${ }^{\mathrm{d}}$ Radiation therapy (RT) was given at a dose of 6 Gy/fraction 


\section{Figure legends}

Fig. 1: Tumour growth of differently treated M2 xenografts in nude mice. (A) Growth curves and (B) tumour growth delay. M2 canine melanoma cells $\left(1 \times 10^{7}\right)$ were inoculated subcutaneously within the left upper thigh region. Tumour treatment was started when the volume reached a size of $500 \pm 50 \mathrm{~mm}^{3}$. On 4 consecutive days, mice were treated with PTK787/ZK 222584 (100mg/kg) and/or received radiation therapy (4 x 6 Gy) (see arrows). Tumour size was recorded twice a week until tumours reached a volume of $1500 \pm 150 \mathrm{~mm}^{3}$. Each curve represents the mean tumour volume per group $(n=8-11$ animals per group) \pm SE.

Fig. 2: Vascularity and perfusion during and after treatment. Contrast-enhanced power Doppler US was performed on day 1 and 4 of treatment (d1 and d4), 4 and 8 days after treatment (d8 and d12) and when tumours had reached the final size of $1500 \pm 150 \mathrm{~mm}^{3}$ (end). Overall tumour perfusion (CWFA) (A) and vascularity (FA) (B) were calculated. No significant differences in perfusion and vascularity were observed between and within treatment groups. *At the end of the study, perfusion and vascularity were significantly lower in all tumours $(P=0.0013(\mathrm{CWFA})$ and $P=0.0002(\mathrm{FA})$ ).

Fig. 3: Contrast-enhanced power Doppler US images of a representative M2 xenograft on day 1 (start of therapy) (A) and at the end of the study (B). At the end of the study, vascularity and perfusion were significantly lower in all tumours. 
Fig. 1
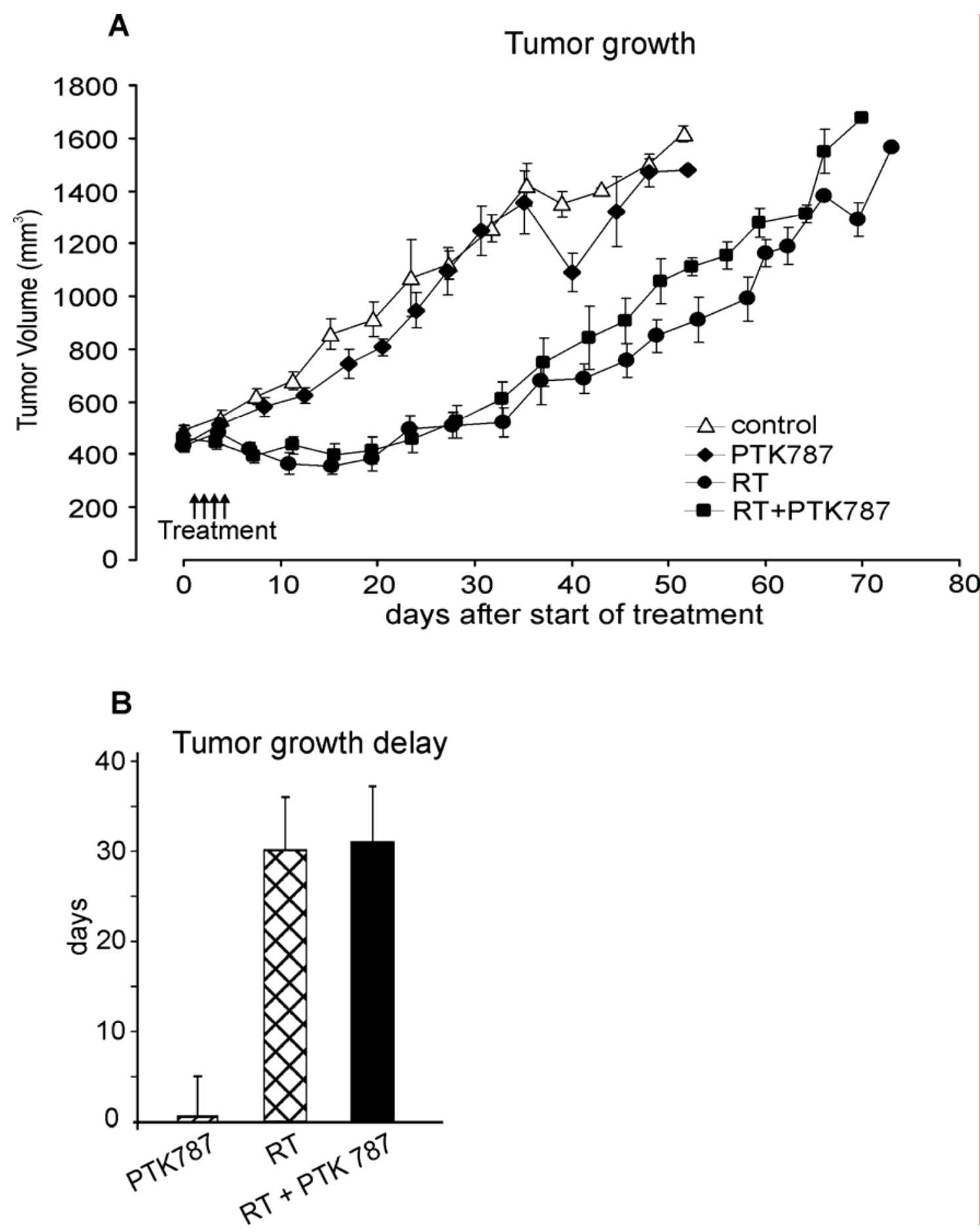
Fig. 2

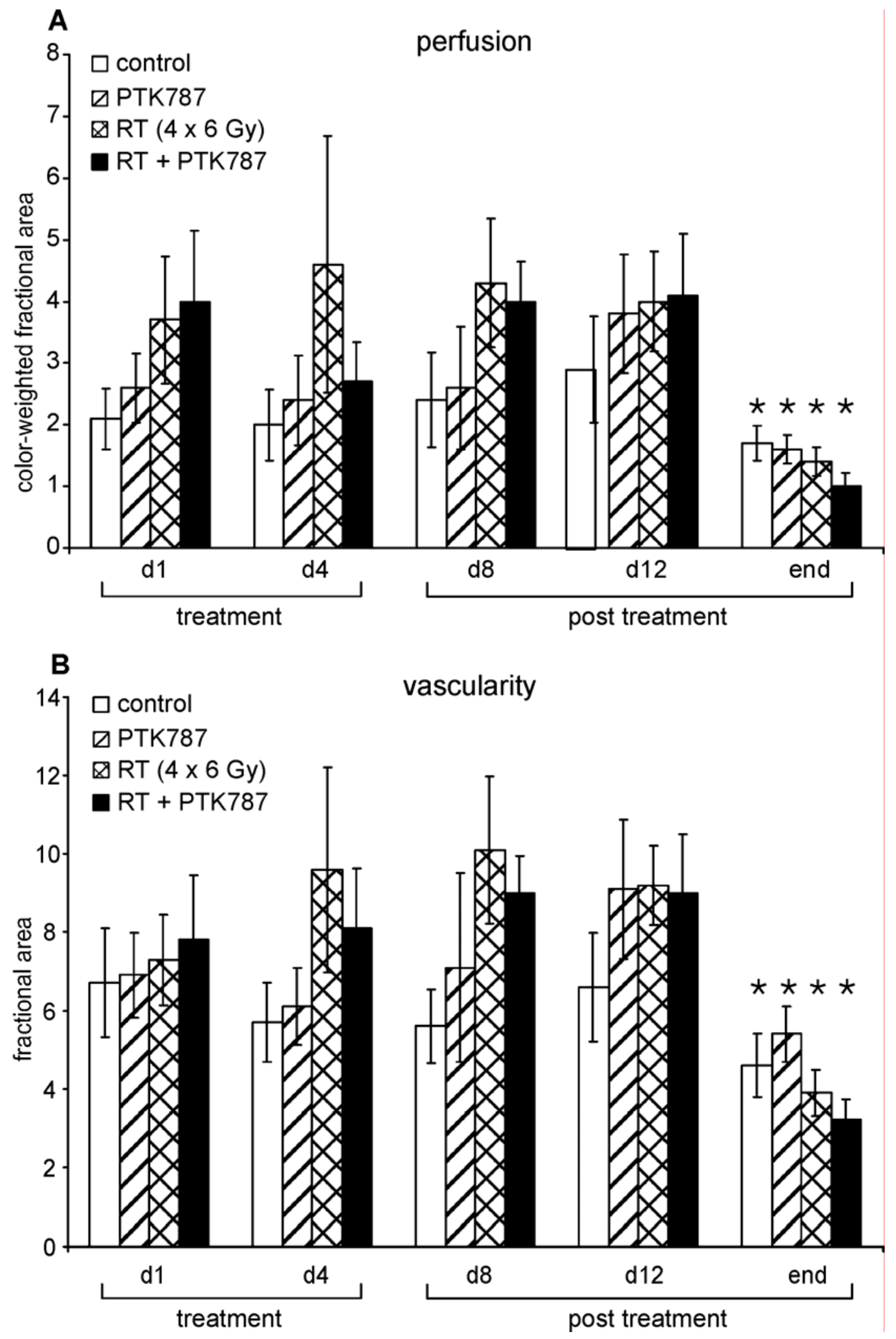


Fig. 3.
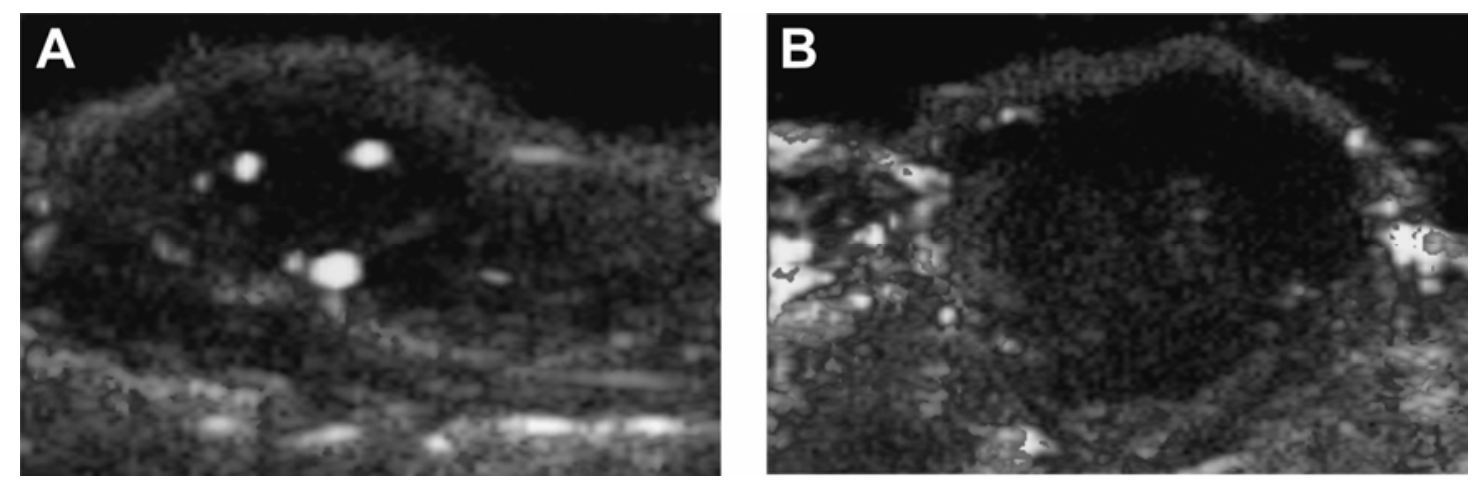


\section{Danksagung}

An dieser Stelle möchte ich mich herzlich bedanken bei allen, die an der Vervollständigung meiner Doktorarbeit beteiligt waren. Mein ganz spezieller Dank gilt:

Frau Prof. Dr. med. vet. Barbara Kaser-Hotz, meiner Referentin. Neben der Bereitstellung des Themas und der finanziellen Unterstützung des Doktorates bedanke ich mich für ihren Enthusiasmus für das Projekt und ihre unerlässliche Hilfe, die verschiedenen Hürden des Doktorates zu meistern.

Herrn Prof. Dr. med. vet. Max Gassman, meinem Korreferenten. Danke für die wissenschaftliche Unterstützung, den stetigen Optimismus und die bedingungslose Bereitstellung aller notwendigen Utensilien und Labors am Veterinärphysiologischen Institut.

Dr. med. vet. Stefanie Ohlerth, die wahrscheinlich am meisten mit mir durch die Hochs und Tiefs des Projektes gegangen ist! Danke für die stets positive Unterstützung, die wertvollen Ratschläge und das gemeinsame Lachen!

Dr. Gisele Höpfl, die mir die Arbeiten im Labor extrem erleichtert hat und mir immer mit gutem Rat, Enthusiasmus und Humor zur Seite stand.

Dr. med. vet. Melanie Wergin und PD Dr. med.vet. Franco Guscetti für ihre unverzichtbare Hilfe bei der Vervollständigung des Manuskripts.

Dr. med. vet. Carla Rohrer Bley, die nicht nur eine hervorragende Arbeitskollegin, sondern auch eine wunderbare Freundin ist.

Stephan Keller, Dr. Lara Ogunshula und Dr. Thomas Hofer für wertvolle Tipps, Diskussionen und vorbehaltlose Hilfe für das Arbeiten im Veterinärphysiologischen Labor. Nicht zu vergessen die stets positive und freundliche Arbeitsatmosphäre im gesamten Labor und die freitäglichen z'Nüni.

Allen, die mir eine wunderbare Zeit in Zürich ermöglicht haben, die wertvolle Erinnerungen mit sich trägt. 


\section{Curriculum vitae}

\begin{tabular}{|c|c|}
\hline Name & Natalie Inteeworn \\
\hline Geburtsdatum & 4. Januar 1976 \\
\hline Geburtsort & Neunkirchen/Saar \\
\hline Nationalität & Deutsch \\
\hline $1982-1986$ & Grundschule Schmelz-Hüttersdorf \\
\hline $1986-1995$ & Johannes-Kepler Gymnasium Lebach, Deutschland \\
\hline 1995 & Abitur \\
\hline $1995-2000$ & $\begin{array}{l}\text { Studium der Veterinärmedizin an der Tierärztlichen Hochschule } \\
\text { Hannover, Deutschland }\end{array}$ \\
\hline 2001 & Approbation an der Tierärztlichen Hochschule Hannover, Deutschland \\
\hline 2001 - 2004 & $\begin{array}{l}\text { Doktorat, Abteilung für Bildgebende Verfahren und Radio-Onkologie, } \\
\text { Vetsuisse-Fakultät Universität Zürich } \\
\text { Leitung: Prof. Dr. med. vet. B. Kaser-Hotz }\end{array}$ \\
\hline $2004-2005$ & $\begin{array}{l}\text { Internship für Kleintiermedizin und -chirgurgie, Virginia-Maryland } \\
\text { Regional College of Veterinary Medicine, Blacksburg, USA }\end{array}$ \\
\hline ab 2005 & $\begin{array}{l}\text { Residency, Innere Medizin, Virginia-Maryland Regional College of } \\
\text { Veterinary Medicine, Blacksburg, USA }\end{array}$ \\
\hline
\end{tabular}

